\title{
PENGALAMAN ORANG TUA DENGAN ANAK YANG MENGALAMI HOSPITALISASI DI RUANG PERAWATAN \\ ANAK RUMAH SAKIT SWASTA YOGYAKARTA
}

\author{
Margareta Hesti Rahayu ${ }^{1}$
}

${ }^{1}$ STIKes Panti Rapih Yogyakarta, retha.ignaxandria@gmail.com

\begin{abstract}
ABSTRAK
Latar Belakang: Saat anak dirawat di rumah sakit, orang tua ikut merasa stress. Lima puluh persen orang tua memiliki kecemasan tingkat berat dan $30 \%$ orang tua mengalami panik saat anaknya pertama kali dirawat.

Tujuan: Untuk mengetahui pengalaman orang tua dengan anak yang mengalami hospitalisasi.

Metode: Penelitian ini merupakan penelitian deskriptif kualitatif yang dilakukan di salah satu rumah sakit swasta di Yogyakarta. Partisipan dalam penelitian dipilih menggunakan purposive sampling. Pengumpulan data dilakukan pada tahun 2017. Instrumen penelitian ini menggunakan kuesioner dan pedoman wawancara. Penelitian ini telah mendapatkan ijin ethical cleareance dari komite etik Universitas Ahmad Dahlan. Analisis data menggunakan analisis deskriptif kualitatif.

Hasil: Respon emosional yang muncul pada orang tua adalah sedih, menangis, cemas, dan khawatir. Respon emosional anak adalah menangis, takut, cemas dan munculnya rasa bosan. Sedangkan respon emosional saudara kandung adalah cemas dan khawatir. Perilaku dan sikap orang tua adalah dengan berdoa dan mencoba ikhlas dan sabar. Dukungan yang diberikan orang tua maupun perawat dengan cara memberikan kesempatan pada anak untuk bermain dan mengobrol. Harapan orang tua adalah anaknya dapat segera sembuh dan mendapatkan informasi yang jelas tentang kondisi anaknya.

Simpulan: Ada 4 tema yang ditemukan pada orang tua dengan anak yang dirawat di rumah sakit yaitu: respon emosional, perilaku dan sikap orang tua, kekhawatiran orang tua dan harapan orang tua.
\end{abstract}

Kata kunci: pengalaman orang tua, anak, hospitalisasi 


\begin{abstract}
Background: When children are hospitalized, parents feel stressed. Fifty percent of parents have severe anxiety and $30 \%$ of parents experience panic when their child is first hospitalized.

Objective: to explore parent's experience with hospitalized children.

Methods: This research is a qualitative descriptive study conducted at a private hospital in Yogyakarta. Data was collected in 2017. Participants in the study were selected using purposive sampling. This research instrument uses a questionnaire and interview guidelines. This research has received an ethical cleareance permit from the Ethics Committee of Ahmad Dahlan University. Data analysis use qualitative descriptive.

Results: Emotional responses that arise in parents are sad, crying, anxiety, and worry, the emotional response of children is crying, fear, anxiety and the appearance of boredom, while the emotional response of siblings is anxiety and worry. The behavior and attitude of parents is to pray and try to be sincere and patient. Parents and nurses give support by providing opportunities for children to play and chat. Parents hope that their children can get well soon and get clear information about their child's condition.
\end{abstract}

Conclusion: There are 4 theme in this research, emotional response, the parents' behaviour and attitude, Support dan Parents hope.

Keywords: parents expereince, children, hospitalized

\title{
PENDAHULUAN
}

Anak yang dirawat di rumah sakit mengalami kecemasan dengan keadaan tempat tidur, minimnya tempat tidur, aktivitas rutin rumah sakit dan asing terhadap perawat serta staf ruangan (BasiriMoghaddam, Sadeghmoghaddam, \& Ahmadi, 2011). Anak yang dirawat di rumah sakit memiliki masalah yang serius yang disebabkan adanya perpisahan dengan orang tua, penyesuaian diri terhadap lingkungan yang asing, dan tindakan perawatan yang menyebabkan anak menjadi tidak nyaman dan kadang menyakitkan (Utami, 2014). Reaksi emosional pada anak yang di rawat di rumah sakit tergantung pada jenis dan kuantitas stress yang disebabkan oleh penyakit itu sendiri, pengalaman hospitalisasi dan persepsi anak terhadap situasi 
tersebut. Anak yang dirawat di ruang perawatan kritis mengalami stress yang cukup signifikan dan merupakan pengalaman yang paling menakutkan. Anak yang mengalami penyakit kritis menyebabkan anak mengalami ketakutan, kecemasan, dan anak menjadi pendiam (Urden, Stacy \& Lough, 2009). Ibu merasa cemas dan sedih ketika anaknya harus dirawat di rumah sakit. Umumnya reaksi orang tua saat anak harus dirawat adalah munculnya perasaan sedih, cemas dan frustasi dan kekhawatiran tentang kondis anaknya (Maria, Indriati \& Rahmalia, 2011). Orang tua dengan anak yang menderita penyakit kronis misalnya kanker memiliki tingkat emosional yang lebih tinggi dan masalah psikosomatis yang lebih sering dibandingkan populasi normal (Hoekstra-Weebers, 2012). Anak yang mengalami sakit atau cedera akan memberi dampak pada setiap anggota keluarga. Sebuah stressor yang menimpa keluarga membutuhkan respon dari keluarga yang dapat mengubah cara interaksi dengan anggota keluarga dan dengan orang lain (Ball, 2012).
Kecemasan pada orang tua saat menghadapi hospitalisasi anak dipengaruhi oleh jenis penyakit yang diderita anak, lamanya hospitalisasi pada anak, dan pengalaman orang tua dalam mendampingi hospitalisasi anak (Fadila, 2018). Kecemasan tingkat berat terjadi pada orang tua yang anaknya baru pertama kali dirawat. Lima puluh persen orang tua memiliki kecemasan tingkat berat dan $30 \%$ orang tua mengalami panik saat anaknya pertama kali dirawat (Sugihartiningsih, 2016). Kecemasan pada orang tua yang mendampingi anak di rumah sakit, menyebabkan orang tua mengalami gangguan kualitas tidur yang disebabkan kesulitan untuk mengelola emosi dirinya sendiri dan anaknya yang mempengaruhi relasi antara anak dan orang tua. Dampak dari penurunan kualitas tidur pada orang tua adalah orang tua kesulitan mengambil keputusan pada perawatan anaknya (Stickland, et.al., 2016). Rasa cemas orang tua juga ditunjukkan dengan sering bertanya dan mencari informasi tentang kondisi anaknya (Wong, et. al., 2009). Dampak pada orang tua 
lainnya adalah orang tua mengalami penurunan nafsu makan dan yang paling esktrem adalah karena tuntutan ekonomi ada orang tua yang harus masuk penjara karena mencari biaya pengobatan anaknya (Maria, Indriati, \& Rahmalia, 2017).

Pada tahun 2016 jumlah anak yang di rawat di salah satu rumah sakit swasta di Yogyakarta sejumlah 2797 anak, jumlah menunjukkan peningkatan dari tahun sebelumnya yaitu 2518 anak. Anak yang dirawat di rumah sakit seringkali tidak kooperatif karena kecemasan yang dialaminya sehingga menimbulkan kecemasan pada orang tua. Orang tua yang selama 24 jam menunggu anaknya di rumah sakit seringkali mengalami kecemasan, penurunan nafsu makan dan kualitas tidur selama berada di rumah sakit. Berdasarkan fenomena diatas bagaimana pengalaman orang tua saat menghadapi hospitalisasi pada anak di ruang anak. Penelitian ini bertujuan untuk mengetahui gambaran orang tua saat menghadapi hospitalisasi pada anak di ruang anak.

\section{METODE PENELITIAN}

Penelitian ini merupakan penelitian deskriptif kualitatif yang dilakukan di salah satu rumah sakit swasta di Yogyakart yang dilakukan pada bulan Oktober sampai dengan November tahun 2017. Sampel diambil dengan cara purposive sampling yaitu orang tua dapat ayah atau ibu, namun dalam penelitian ini semua responden adalah ibu karena orang tua yang merawat anaknya selama 24 jam dan memiliki skor stress tinggi.

$$
\text { Instrumen menggunakan }
$$

kuesioner dan pedoman wawancara. Kuesioner yang digunakan adalah PSS (Parental Stress Scale) untuk mengukur tingkat stress pada orang tua. Pedoman ini berisi 14 pertanyaan untuk keluarga. Pedoman wawancara yang digunakan sebelumnya sudah dilakukan uji pemahaman. Proses pengumpulan data diawali dengan cara meminta orang tua mengisi kuesioner PSS dan setelah mendapatkan orang tua dengan stress tinggi, peneliti memohon ijin pada orang tua untuk melakukan wawancara. Peneliti 
melakukan wawancara pada 5 orang tua dan 2 perawat untuk melakukan triangulasi sumber. Wawancara dilakukan saat orang tua berada di rumah sakit, di kamar perawatan ataupun di teras kamar pasien, pada saat anak dalam kondisi tenang atau saat anak tidur. Wawancara yang dilakukan adalah wawancara semi terstruktur dengan lama wawancara 60-90 menit. Triangulasi sumber dilakukan pada 2 perawat yang merawat anak dengan orang tua yang terpilih sebagai responden.

Etika dalam penelitian yang harus diperhatikan meliputi: kerahasiaan dan informed consent. Penelitian ini telah mendapatkan ijin ethical cleareance dari komite etik Universitas Ahmad Dahlan.

\section{HASIL DAN PEMBAHASAN}

Karakteristik Partisipan

Tabel 1 Karakteristik Partisipan

\begin{tabular}{|c|c|c|c|c|}
\hline $\begin{array}{c}\text { Parti } \\
\text { sipan }\end{array}$ & Umur & $\begin{array}{c}\text { Pekerja } \\
\text { an }\end{array}$ & $\begin{array}{c}\text { Usia } \\
\text { Anak }\end{array}$ & $\begin{array}{c}\text { Usia } \\
\text { saudara }\end{array}$ \\
\hline P1 & 50 tahun & Swasta & 14 tahun & 20 tahun \\
P2 & 48 tahun & IRT & 8 tahun & 12 tahun \\
P3 & 40 tahun & IRT & 9 tahun & 12 tahun \\
P4 & 48 tahun & IRT & 10 tahun & 15 tahun \\
P5 & 40 tahun & Swasta & 8 tahun & 15 tahun \\
\hline
\end{tabular}

Sumber: data primer
Perawat 1 adalah seorang wanita, bekerja sebagai perawat anak selama 4 tahun. Perawat 2 adalah juga seorang wanita, bekerja sebagai perawat anak selama 7 tahun.

Hasil wawancara yang didapatkan dari orang tua dan perawat didapatkan 4 tema yaitu: respon emosional, sikap orang tua, kekhawatiran orang tua dan harapan orang tua.

1. Respon mosional anak, orang tua dan saudara kandung

a. Respon emosional anak

Respon emosional yang muncul pada anak saat anak dirawat di rumah sakit adalah menangis, takut, cemas dan munculnya rasa bosan.

Partisipan 3: "Ya nangis.. Tadinya dia nggak mau cuman ya tak bilang biar cepat sembuh gitu."

Partisipan 5: "Ya awalnya sih ya cemas gitu terus kalau apa lihat hasilnya kok terus nganu ya memang ada kecemasan. Tambah cemas gitu”

Perawat 1: "Kalau anak-anak biasanya itu khawatir cemas yang pasti itu kadang ada yang takut gitu kan karena mereka sudah mengerti to mau diapain takut disuntik 
mau diapain... Nangis biasanya"

Partisipan 4: "Aku bosen $e$ mah ingin pulang gitu."

Respon emosional pada anak berupa menangis, takut, dan cemas disebabkan oleh beberapa hal berikut ini: merasa tidak nyaman, merasakan sakitnya, takut jika disuntik, rasa bosan selama di rumah sakit, dan belum pernah dirawat di RS sebelumnya. Hal ini disampaikan oleh orang tua dan perawat di ruang anak.

Partisipan 3: "Ya itu karena memang takut disuntik aja sebetulnya..."

Partisipan 2: "Karena sakit kepalanya itu."

Perawat 1: "Kalau anak-anak biasanya itu khawatir cemas yang pasti itu kadang ada yang takut gitu kan karena mereka sudah mengerti to mau diapain takut disuntik mau diapain..."

b. Respon emosional orang tua

Respon emosional yang muncul pada orang tua adalah sedih, menangis, cemas, dan khawatir. Hal ini diungkapkan oleh orang tua dan perawat.

Partisipan 1: "Pasti selalu cemas ya suster apalagi dengan kondisi dia kayak gini ya aku selalu cemas aja

Partisipan 2: "Ya sedih karena gimana ya (tertawa) harus bolak balik kesini pengennya dia apa sehat gitu, pengennya cepat sembuh, iya."

Partisipan 5: "Ya cemas yang pasti cemas khawatir, apa ya ya kalau lelah ya mesti ada tapi kan intinya nggak terlalu dibuat itu."

Perawat 2: "Ya, e... macammacam juga ya bu ya ada yang cemas, ada yang sedih, terus, e... takut juga khawatir seperti itu."

Rasa khawatir pada orang tua adalah khawatir terjadinya hal yang buruk pada anak, penyakit anak dan tindakan yang dilakukan pada anaknya. Hal ini diungkapkan oleh orang tua dan perawat di ruang perawatan anak.

Partisipan 3: "Ya saya khawatir mungkin takut dia ada penyakit apa itu tu."

Partisipan 4: "E.. sedihnya ketika dia nangis merasakan kesakitan iritasi itu sus terus dia harus bolak balik ke 
belakang terus dia sampe jalan saja e susah."

Perawat 2: "Yang dikhawatirkan itu biasanya tentang ini sih penyakitnya apa gitu bu terus tindakannya bagaimana saja terus kedepannya itu bagaimana gitu sih bu."

c. Respon emosional saudara kandung

Respon emosional yang muncul dari saudara kandung anak adalah cemas dan merasa khawatir dengan saudaranya yang sedang sakit.

Partisipan 4: "Reaksi mereka tanya bagaimana ma D harus opname, iya... ya apa memang mereka ada rasa khawatir.."

Partisipan 5: "Ikut cemas juga, he'e soalnya tau juga pas saat kejangnya itu jadi kan dia.. He'e. Pas diawal itu kan nggak pas nggak ada yang nunggu jadi kan ikut ikut pas dirujuk ke itu juga ikut jadi kan tau... . Terus saat ini dia nggak berani di dalam mintanya di luar terus."

2. Perilaku dan sikap orang tua untuk mengurangi kecemasannya.

Perilaku dan sikap orang tua ketika mendampingi anak saat dirawat di rumah sakit adalah dengan berdoa, mencoba ikhlas, dan sabar dengan kondisi yang terjadi saat ini.

Partisipan 2: "Ya mencoba kayak opo me.. opo ikhlas gitu. kita ikhlas terus berdoa untuk anak saya gitu."

Partisipan 4:" Kalau ya saya cuman bisanya ya berdoa ho'o itu aja sampe ya Tuhan berikan petunjuk saya, saya sabar ya itu sus cuman itu aja sih ya.."

3. Dukungan untuk mengurangi dampak hospitalisasi anak

Dukungan yang diberikan untuk anak dari orang tua maupun perawat dengan cara memberikan kesempatan pada anak untuk bermain dan mengobrol.

Partisipan 2: "Ya cuma ya ngobrol diajak ngobrol sama kakaknya tu bercanda gitu.."

Partisipan 3: "Ya itu cuman main game, paling duduk di depan, jalan, gitu aja."

Perawat 1: "Biasanya kalau kita di sini ada terapi bermain jadi nanti ada balon kadang dikasih balon terus mewarnai kalau anak-anak usia sekolah kan sudah bisa mewarnai. Sama biasanya ada playland di situ main-main" 
Perawat 2: "Kejenuhan, e.. ya kita bisa memberikan fasilitas misalnya kursi roda untuk jalanjalan gitu bu atau fasilitas kayak healing garden gitu kan ada untuk hiburan musik, nyanyi seperti itu atau terapi-terapi bermain yang di ruang bermain itu."

Dukungan lainnya yang diberikan pada anak oleh orang tua adalah mengajak anak untuk berdoa, memberikan sentuhan fisik saat anak merasa sakit, memeluk anak saat anak merasa takut, dan memberikan pengertian pada anak.

Partisipan 1: "Ya saya hanya selalu bilang bahwa intinya ya itu harus kita jalani adek harus sabar kita harus banyak berdoa."

Partisipan 3: "Ya tak tutup, tak peluk aja. Tak peluk terus apa mukanya nggak usah lihat apa jarum disuntikin itu terus tak ajak ngobrol gitu aja."

Perawat 2: "E.. biasanya ya tetep membujuk dengan baik, memberitahu gitu memberi tahu dengan baik."

4. Harapan orang tua saat anak mengalami hospitalisasi

Harapan orang tua saat anaknya sakit adalah anaknya dapat segera sembuh dan mendapatkan informasi yang jelas tentang kondisi anaknya.

Partisipan 2: "Ya cepat sembuh, cepat keluar dari rumah sakit biar bisa beraktivitas belajar kembali gitu."

Partisipan 3: "E. ya informasi. Informasi yang makusdnya e. anak saya ini sakitnya apa misalnya kan dipriksa diambil ininya labnya hasilnya apa. Jadi pokoknya informasi aja yang membuat saya akhirnya tu nanti kalau suster atau dokter bilang oh nggak pa-pa bu ini hasilnya baik itu baru saya ayem."

\section{PEMBAHASAN}

1. Respon Emosional

Respon emosional yang muncul pada anak saat anak dirawat di rumah sakit adalah menangis, takut, cemas, dan munculnya rasa bosan. Hasil penelitian ini sejalan dengan hasil penelitian Rahmawati \& Bhinekawati (2012) bahwa anak yang masuk rumah sakit akan mengalami respon hospitalisasi berupa menangis, berteriak, sedih, menghindar, dan menolak kepada orang lain, tidak tertarik dengan 
lingkungan, sedih dan menarik diri dengan lingkungan

Respon emosional yang muncul pada orang tua adalah sedih, menangis, cemas, dan khawatir. Hasil penelitian ini sesuai dengan hasil penelitian Maria, Indriati, \& Rahmalia (2017) bahwa respon orang tua dengan anak hospitalisasi adalah sedih. Penelitian serupa juga dilakukan oleh Mariyam \& Kurniawan (2008) dan didapatkan data bahwa orang tua mengalami kecemasan saat anaknya mengalami hospitalisasi, dan hal ini dipengaruhi oleh usia, jenis kelamin, tingkat pendidikan, status sosial ekonomi, tingkap pengetahuan, lama rawat inap, dan perilaku caring perawat.

Sebagian besar orang tua ingin terlibat dalam tindakan perawatan anaknya, ingin terlibat dalam pengambilan keputusan dan ingin didengar keluh kesahnya, maka perawat sebagai tenaga kesehatan perlu melibatkan keluarga dalam setiap aspek asuhan keperawatan yang diberikan pada anak. (Kyle \& Carman, 2015).
Respon emosional juga muncul dari saudara kandung anak, respon tersebut berupa rasa cemas dan khawatir. Saudara kandung anak merasa khawatir dengan kondisi saudaranya yang dirawat di rumah sakit. Perasaan takut dan cemas tentang keadaan saudaranya yang dirawat di rumah sakit dapat muncul karena kurang pengetahuan tentang kondisi saudaranya dan tidak ada saudaranya saat di rumah. Reaksi saudara kandung yang lain adalah rasa marah, cemburu, benci, dan rasa bersalah. Rasa marah, cemburu, dan benci muncul karena orang tua lebih memprioritaskan saudaranya yang sakit, dan merasa marah dengan situasi yang tidak menyenangkan (Supartini, 2014).

2. Perilaku dan sikap orang tua untuk mengurangi kecemasannya Perilaku dan sikap orang tua ketika mendampingi anak saat dirawat di rumah sakit adalah dengan berdoa dan mencoba ikhlas dan sabar dengan kondisi yang terjadi saat ini. Sebagian 
besar orang tua berdoa ketika menghadapi masalah, ataupun mengalami kesulitan. Penelitian yang dilakukan oleh Maria, Indriati \& Rahmalia (2017), didapatkan hasil bahwa ketika anaknya sakit orang tua berusaha untuk ikhlas dan banyak berdoa untuk kesembuhan anaknya. Berdoa membuat seseorang merasa lebih tenang dan damai, serta merasa lebih kuat ketika menghadapi permasalahan yang muncul dalam hidupnya. Menurut orang tua pasien, berdoa membuat merasa lebih sabar untuk menjalani dan menghadapi yang terjadi.

3. Dukungan untuk mengurangi dampak hospitalisasi anak

Dukungan yang diberikan untuk anak dari orang tua maupun perawat dengan cara memberikan kesempatan pada anak untuk bermain dan mengobrol. Bermain dapat menurunkan tingkat kecemasan anak, hal ini sejalan dengan penelitian yang dilakukan oleh Sholikah (2011) bahwa theraupetic peer play berpengaruh terhadap kecemasan dan kemandirian anak dalam hal ini dapat menurunkan kecemasan anak saat hospitalisasi.

Ketika anak usia sekolah sakit, ia menerima kondisinya saat harus sakit, terbaring di tempat tidur dan tidak bisa melakukan aktivitas yang membutuhkan banyak energi. Anak akan melakukan katarsis, melakukan aktivitas bermain dengan berimaginasi berperan sebagai petugas kesehatan yang akan melakukan prosedur perawatan. Anak merindukan rutinitas mereka saat sebelum sakit dan hal ini berubah karena anak harus dirawat di rumah sakit. Hospitalisasi mengubah rutinitas mereka dan anak berhadapan dengan realitas yang asing (Lapa \& de Souza, 2011).

Dukungan lainnya yang diberikan pada anak oleh orang tua adalah mengajak anak untuk berdoa, memberikan sentuhan fisik saat anak merasa sakit, memeluk anak saat anak merasa takut, dan memberikan pengertian pada anak. Pelukan terapeutik 
meningkatkan kontak fisik erat antara anak dan orang tua dapat digunakan untuk menenangkan anak. Pelukan ini dapat dilakukan orang tua untuk mengurangi ketakutan dan kecemasan dan sebagai bentuk dukungan orang untuk anaknya (Kyle \& Carman, 2013).

4. Harapan orang tua saat anak mengalami hospitalisasi

Harapan orang tua adalah anaknya dapat segera sembuh dan mendapatkan informasi yang jelas tentang kondisi anaknya. Setiap orang tua berharap kesembuhan untuk anaknya yang sedang sakit dan orang tua mengharapkan informasi yang jelas tentang kondisi sakit anaknya dan prosedur tindakan yang akan dilakukan. Orang tua seringkali tidak siap dengan perubahan dan kondisi yang terjadi pada anaknya yang mengalami hospitalisasi. (Kyle \& Carman, 2013).

Keterbatasan penelitian ini adalah jenis penyakit pada anak tidak spesifik penyakit akut atau kronis sehingga respon orang tua pasti akan berbeda.

\section{KESIMPULAN DAN SARAN}

\section{Kesimpulan}

Orang tua khususnya ibu memiliki peran yang sangat besar saat mendampingi dan memberikan dukungan anak yang sakit, namun demikian orang tua juga membutuhkan dukungan dan informasi yang jelas tentang tindakan perawatan pada anaknya.

\section{Saran}

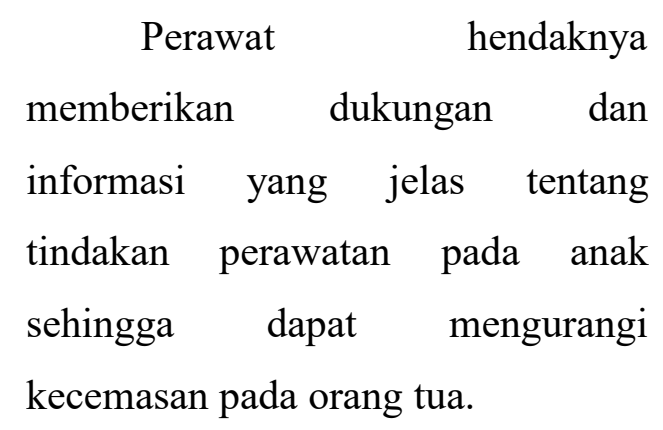

\section{DAFTAR PUSTAKA}

Fadila, Aziza Zukruf Budi. (2018). Kecemasan orang tua menghadapi hospitalisasi anak.

http://eprints.ums.ac.id/67773 
Ball Jane, Ruth Blinder, Kay Cowen. (2012). Principle of pediatric nursing carring for children. Pearson.

Basiri-Moghaddam, K., BasiriMoghaddam, M., Sadeghmoghaddam, L., Ahmadi, F. (2011). The Concept of Hospitalization of Children from the View Point of Parents and Children. Iranian Journal of Pediatrics, 21(2), 201-208.

Hoekstra-Weebers, Josette EHM. Wijnberg-Williams, Barbara. Jasper, Jan PC. Kamps, Willen A (2012). Coping and its effect on psychological distress of parents of pedaitric cancer patients: a longitudinal prospective study. PsychoOncology. Winley online library.

Kyle, Terri., \& Carman, Susan. (2013). Buku Ajar Keperawatan Pediatri. EGC.

Lapa, D. de F., \& de Souza, T. V. (2011). [Scholars' perception about hospitalization: contributions for nursing care]. Revista Da Escola De Enfermagem Da US P, 45(4), 811-817.

Maria, Avanty., Indriati, Ganis., Rahmalia, Siti. (2011). Pengalaman ibu dalam merawat anak dengan Leukemia.

Repository.usu.ac.id/bitsream/ 123456789/14257/1/09ED104 7.pdf. diakses pada tanggal 2 Februari 2018.
Solikhah, Umi. (2011). Pengaruh therapeutic peer play terhadap kecemasan dan kemandirian anak usia sekolah selama hospitalisasi di Rumah Sakit wilayah Banyumas. lib.ui.ac.id.

Stickland, A., Clayton, E., Sankey, R., \& Hill, C. M. (2016). A qualitative study of sleep quality in children and their resident parents when in hospital. Archives of disease in childhood, 101(6), 546-551.

Sugihartiningsih. (2016). Gambaran tingkat kecemasan orang tua terhadap hospitalisasi anak di RSUD dr. Moewardi. PROFESI.Volume 13. Nomor 2. Maret 2016.

Supartini, Yupi. (2014). Buku Ajar Konsep Dasar Keperawatan Anak. EGC.

Utami, Yuli. (2014). Dampak hospitalisasi terhadap perkembangan anak. Jurnal ilmiah Widya. Volume 2 Nomor 2. Mei-Juli 2014.

Urden, Linda D., Stacy, Kathleen M., Lough, Mary E. (2009).

Critical Care Nursing: Diagnosis and Management. Mosby.

Wong, Donna L., Hockenberry, Marilyn., Wilson, David., Winkelstein, Marilyn L., Schwart, Patricia. (2009). Buku Ajar Keperawatan Pediatrik. EGC. 